\title{
BOEKANIERS EN FLIBUSTIERS
}

$$
\text { DOOR }
$$

C. K. KESLER

Het was werkelijk niet de bloem der natiën, die in de 16 e en 17e eeuw uit Europa naar Oost- en West uitzwerde om in de kort geleden ontdekte streken een nieuw veld van werkzaamheid te zoeken. Allerlei redenen, lust tot avonturen, moeilijk te breidelen vrijheidszucht, tegenzin in onderwerping aan kerkelijken dwang en niet het minst conflicten met de wetten huns lands brachten er honderden toe, Europa den rug toe te keeren en hun fortuin elders te zoeken. Elders, dat was voor velen aan de overzijde van den Oceaan, in de West, vanwaar men hoorde, dat fabelachtige rijkdommen jaarlijks naar Spanje werden overgevoerd, schatten, die de Habsburgers in staat zouden stellen, hun macht over de geheele bewoonde wereld te doen gevoelen Daar, in de Nieuwe Wereld lokte een toekomst hen, die daarvan in de oude wereld niets meer te verwachten hadden. Daar waren wonderschoone landstreken, fabelachtige schatten, vreemde menschen en dieren, daar waren ook de nederzettingen der Spanjaarden, in wier havens de rijkgeladen galjoenen zich verzamelden voor den overtocht naar het moederland, en - een ernstig punt van overweging voor niet weinigen, tot daar reikte niet de straffende arm der gerechtigheid. Verschillende getuigenissen zijn er bewaard, die aantoonen, dat het meerendeel der naar de West geëmigreerden het een of ander met de justitie in het moederland te vereffenen hadden en zich door de vlucht straffeloosheid trachtten te verzekeren. Zelfs maakte, ofschoon zij op andere tijden weer van een haast moederlijke zorg ervoor doet blijken, reeds vroeg de Spaansche regeering nu en 
dan gebruik van de Amerikaansche koloniën om ongewenschte elementen te verwijderen en tegelijkertijd in het gebrek aan werkkrachten daarginds te voorzien. Bij gelegenheid van de voorbereiding van de derde reis van Columbus reeds kregen de rechters in het koninkrijk machtiging, ter dood veroordeelde mannen en vrouwen over te leveren aan de agenten van den admiraal voor deportatie naar Hispaniola. Omstreeks anderhalve eeuw later, ongeveer 1670, klaagde José Veitia de Linaje, lid en penningmeester van het Casa de la Contratación te Sevilla in zijn werk ,La Norte de la Contratación de las Indias Occidentales" erover, dat door onvoldoende toezicht op degenen, die zich in scheepten, ,de Nieuwe Wereld vervuld werd met vagebonden". De hierna te vermelden Franschman De Pointis verklaart na zijne ervaringen in de West in 1698: „Allen, die in Frankrijk voor vagebondage worden aangehouden en zich niet kunnen verantwoorden, worden naar deze, (d.i. de Westindische) eilanden gezonden. Daar moeten zij op de plantages werken, maar de meesten zien een geweer te krijgen en worden dan zeeroovers. Ook zijn velen van de schepen gedeserteerd; zij brengen den gouverneurs voordeel aan en worden daarom min of meer beschermd." En bij al die beweegredenen kwam dan nog vaak de werking van atavistische krachten, van duistere, verre herinneringen aan voorouders uit een eeuwenoud, grijs verleden, zeeroovende Saksen en Friezen en Noormannen, die bij niet weinigen in het bloed begonnen te werken. De gezeten burgers ondervonden dien trek naar het avontuurlijke niet zoozeer, het waren eerst vooral de anti-socialen, de mislukten in een eenigszins geordende maatschappij, de geboren avonturiers, die zich opmaakten, om in de Nieuwe Wereld te gaan zoeken, wat de oude hun niet aanbood, vrijheid, rijkdom, zorgeloosheid, bandeloosheid vooral.

Haast in het kielwater der eerste Spaansche schepen begaven zij zich naar de overzijde, minachtende verbodsbepalingen, in Spanje uitgevaardigd, overtredende de beslissing van den $\mathrm{H}$. Stoel, op eigen gelegenheid zoekende naar het Dorado, en desnoods alleen naar het vandaar ge- 
haalde goud, als het land zelf niet te bereiken of onvindbaar bleek. Nog nauwelijks waren de Spanjaarden bezig met hunne veroveringen in Mexico, in Panamá, in Peru, nog ter nauwernood was er iets in wording van de organisatie van hun overzeesch rijk, of reeds zette Cabot, in dienst van Hendrik VII, den voet op het Amerikaansche vastland, kruiste Verrazano's expeditie, uitgezonden door Frans I, langs de Oostkust der tegenwoordige Vereenigde Staten en begonnen vooralFranscheenEngelsche gelukzoekers op eigen gelegenheid hun weg naar de nieuwe streken te zoeken. Sebastiaan Cabot vond in 1526 een Franschen zeeroover in de Allerheiligenbaai in Brazilië, in 1537 vermeesterde een andere Franschman drie Spaansche schepen in de Caraïbische $Z$ ee, verbrandde er twee van en voerde het derde mede naar de Straat van Florida. Dat zijn enkele feiten, die toevallig voor ons zijn bewaard gebleven, maar uit de maatregelen, genomen, of althans beraamd van Spaansche zijde, om den weg der retourvloten iets veiliger, of ten minste iets minder onveilig te maken, blijkt welvoldoende, hoe lastig en gevaarlijk de Westindische zeeroovers reeds in het eerste kwartaal der 16e eeuw begonnen te worden. Sedert 1526 b.v. werd van de kooplieden, betrokken in den overzeeschen handel, in Spanje een belasting geheven, de avería, waarvan de opbrengst moest strekken ter bekostiging der „Armadas de la Guardia de la Carrera de las Indias". Die armada bestond uit een soort politie-vaartuigen, bestemd om te patrouilleeren tusschen Kaap St.-Vincent, de Kanarische eilanden en de Azoren, maar die, wanneer het wegens de onveiligheid der zeeën noodig werd geoordeeld, ook wel koopvaarders naar en van de West begeleidden. Die maatregel was inderdaad noodig; alleen, evenals zooveel, dat in Spanje werd voorgeschreven, werd hij onvolledig en gebrekkig uitgevoerd en weldra maakten verschillende omstandigheden de naleving ervan geheel onmogelijk.

De zeeroovers deden daar hun voordeel mede en niet minder met de gebrekkige uitrusting der Spaansche schepev, met de overlading ervan met koopwaren en edele metalen, waardoor vaak het geschut niet behoorlijk be- 
diend kon worden, niet het minst ook met de onbekwaamheid en minderwaardigheid der Spaansche zeelieden. Minderwaardig in moreel opzicht mochten de desperado's in de Westindische wateren zijn, als zeelieden en vechters overtroffen zij de Spanjaarden verre. Zij hadden dan ook alles te winnen en niets te verliezen, dan hun leven; hun leven, dat slechts geringe waarde voor hen had. Het middelpunt, waar zij zich telkens bij voorkeur verzamelden, werd al spoedig het eiland Tortuga tegenover de Noordkust van Hispaniola. Op zichzelf was dit eiland niet zoo buitengewoon aantrekkelijk, maar aan de piraten bood het verschillende voordeelen. Het was in de nabijheid van Hispaniola en niet te ver van de andere Groote Antillen gelegen, het had een uitstekende haven, waar wel zeventig schepen veilig konden liggen en vooral, de drukst bevaren zeeweg der Spanjaarden was er dicht bij. Later werden nog wel andere eilanden als verzamelplaats door de piraten gebruikt, als zij eens een gezamenlijke onderneming tegen de Spanjaarden op het touw zetten, b.v. Santa Catalina, of Old Providence bij de landengte van Panamá, of het Isla de la Vaca (Ile de la Vache of CowIsland) ten $Z$. van Hispaniola, maar het geliefkoosde middelpunt bleef toch langen tijd Tortuga, het pandemonium van de Caraïbische zee, zooals een schrijver het noemt.

De loop der gebeurtenissen in de Spaansche bezittingen had dit vanzelf veroorzaakt. Hispaniola was in het eerste tijdperk van de Spaansche overheersching het middelpunt van het bestuur geworden. Daar waren de eerste pogingen gedaan, om goud te vinden en de eerste plantages aangelegd. Betrekkelijk spoedig verloor het eiland echter veel van zijn gewicht voor de Spaansche kroon. De Indianen, gedeeltelijk ongeschikt, gedeeltelijk onwillig om voor de nieuwe overheerschers te werken, werden binnen korten tijd zoo goed als uitgeroeid en de aanvoer van negerslaven uit de Portugeesche bezittingen op de Westkust van Afrika begon te laat om het verval van Hispaniola te verhoeden. Geleidelijk werd dit door de meeste Spanjaarden verlaten, velen hunner trokken, toen die streken veroverd waren, naar Mexico, waar zilver en 
vooral naar Peru, waar goud te vinden was en slechts weinigen bleven op Hispaniola achter. Het middelpunt der Spaansche scheepvaartbeweging, weldra ook van het bestuur in Amerika, werd toen Cuba. Dit eiland was geruimen tijd zelf van minder belang, maar de voornaamste haven, Havana, was sedert het midden der 16e eeuw van zooveel gewicht geworden, dat in 1553 besloten werd, den zetel van het bestuur van Santiago op Hispaniola daarheen te verplaatsen. In het daarop betrekking hebbende decreet wordt dit o. a. gemotiveerd door deze overweging: Por ser La Habana lugar de confluencia de navios de todas las Indias y la lava de ellas. (Omdat Havana de plaats waar de schepen van geheel Indië samenkomen en de sleutel ervan is).

Op Hispaniola verviel weldra het grootste gedeelte weer tot den toestand van wildernis; de weelderige tropische plantengroei overwoekerde, wat reeds ontgonnen was, het vee verwilderde en een paar plaatsen aan de kust slechts behielden nog een zwakke Spaansche bezetting. De snelle vermeerdering van de verwilderde runderen en varkens trok jagers aan en in het eerste gedeelte van de 16e eeuw was het binnenland het geliefkoosde jachtterrein geworden voor piraten, vooral van Tortuga, die er hun vleeschvoorraad kwamen aanvullen. Het conserveeren daarvan, voor provisie op de soms maandenlange zwerftochten hunner schepen, hadden zij van de Indianen afgekeken. Deze deden dat op dezelfde wijze, als thans nog hunne stamgenooten in Suriname visch, die zij willen bewaren, bewerken, n.l. door die te rooken boven een smeulend houtvuur, het z.g. barbakotten (Eng. barbacue). Het Fransche woord daarvoor is boucaner, gevormd van het Indiaansche „boucan”. Zulk een „,boucan” is een rooster van takken, rustende op eenige in den grond gestoken gaffels, waarop het aan reepen gesneden vleesch gelegd wordt, nadat onder het rooster een houtvuur is aangemaakt. Zout wordt bij die bewerking weinig of niet gebruikt. Het schijnt, dat van dit woord boucan het bekende woord boekanier is gevormd. Boekaniers waren dus oorspronkelijk jagers en vleeschrookers en, daar de mees- 
ten hunner ook gaarne het bedrijf van zeeroover uitoefenden, kreeg het weldra ook deze laatste beteekenis. Een andere afleiding van het woord boekanier zoekt den oorsprong ervan in het Spaansch woord „buque”, vaartuig.

Boekaniers waren in het begin vooral Franschen. Naar het schijnt, hadden deze zich eerst op Saint-Christophe (St. Kitts) trachten te vestigen, doch waren vandaar verdreven, waarna zij beproefden op Hispaniola een woonplaats te zoeken. Ook hier werden zij echter niet geduld, en begaven zich toen naar Tortuga, waar zij zich staande hielden, in weerwil van herhaalde pogingen der Spanjaarden, om hen ook vandaar te verdrijven. Voortaan bleef dit in Fransche handen; van St. Kitts, dat de Franschen inmiddels opnieuw vermeesterd hadden, werd een Gouverneur gezonden, een zekere Mons. Le Vasseur, die op Tortuga een fort liet bouwen en, zooals boven vermeld is, werd het eiland weldra het middelpunt van allen, die jacht maakten op wilde runderen en varkens en op Spaansche galjoenen. En die allen waren van de meest verschillende nationaliteit; Franschen, Engelschen, Spanjaarden, en.... ook niet weinig. Hollanders. Vooral na het jaar 1625 was voor de Spaansche macht in Amerika een gevaarlijke toestand ingetreden. Gedurende de 16e eeuw had deze rekening te houden gehad met alleenstaande pogingen van allerlei avonturiers, die met of zonder machtiging hunner regeering trachtten, haar te benadeelen. In het eerste kwartaal der 17e eeuw echter begonnen op verschillende punten van het Spaansche overzeesche rijk Franschen, Engelschen en Hollanders hardnekkig te beproeven, zich daar blijvend te vestigen.

Het was in Amerika wel geheel anders geloopen, dan het oorspronkelijke plan der Spaansche monarchen geweest was. Kort na de ontdekking, die voornamelijk de belangstelling van Isabella genoot, was met belangrijke beperkingen de Nieuwe Wereld uitsluitend opengesteld voor emigratie van inwoners van Castilië en Leon. $\mathrm{Na}$ haar dood vergunde Ferdinand ook aan Arragoneezen of andere Spanjaarden, de zee over te steken, mits zij aan bepaalde voorwaarden voldeden. Karel V breidde deze 
vergunning uit tot zijn niet-Spaansche onderdanen. Zoo kwamen reeds in de 16e eeuw Vlamingen, Hollanders en Duitschers voor als inwoners der Spaansche koloniën, vooral de laatsten, wat te verklaren is door de betrekkingen van den keizer met de machtige Zuid-Duitsche bankiers, die hij moest ontzien, wegens den financieelen steun dien zij hem verschaften. Enkelen hunner bevorderden de emigratie van landgenooten en zoo werd zelfs in 1528 een Duitscher, Ambrosius Ehringer, Gouverneur van Venezuela. De latere Habsburgers veranderden deze politiek geheel en vooral onder Filips II werden wanhopige pogingen gedaan, om de vreemde interlopers weer te verdrijven, pogingen, die evenals zooveel, wat Filips ondernam, geheel mislukten. Franschen bleven gevaarlijke tegenstanders, maar vooral Engelschen en Hollanders, de „corsarios luteranos" waren gehaat. Meer en meer breidden de indringers zich uit, hun aanwezigheid moest geduld, ten slotte zelfs noodgedwongen officieel erkend worden. Het eerst geschiedde dit laatste met de Franschen. De bul van Paus Alexander VI, waarbij het Westelijk halfrond aan de Spaansche monarchen werd toegewezen, was voor deze nog steeds de rechtsgrond, waarop zij hunne aanspraken op geheel Amerika grondden. Natuurlijk erkenden Protestantsche natiën, zooals de Engelschen en de Nederlanders die niet, maar voor Katholieken, zooals de Franschen, bleef zij nog tot het midden der 17e eeuw van kracht, daar zij nooit officieel ingetrokken was. Dit veranderde echter in 1658. In een brief van den Paus aan Pater Fontaine, overste der Dominicaansche Missie werd toen de Fransche koning erkend, als bezitter van koloniën in West-Indië, waardoor door den $\mathrm{H}$. Stoel zelf het uitsluitend recht daarop voor de Spaansche kroon was opgeheven. Trouwens, dat was niet meer dan de erkenning van den toestand, die zich langzamerhand in Amerika ontwikkeld had, de opkomst der Franschen, Engelschen en Hollanders en het verval van de Spaansche macht, in het bijzonder in West-Indië.

Hiertoe hadden in niet geringe mate de boekaniers, of flibustiers, zooals zij ook wel genoemd worden, bijgedra- 
gen. De laatste benaming, misschien een verbastering van het Engelsche freebooter, Hollandsch vrijbuiter, misschien ook wel afgeleid van het Hollandsche woord vlieboot, Engelsch flyboat, wees meer in het bijzonder op hunne werkzaamheid, als zeeroovers. Veel verschil was er in den grond der zaak niet tusschen boekaniers en flibustiers; zooals boven reeds vermeld werd, verwisselden, zoo zij daar lust toe gevoelden, de boekaniers hun beroep van jagers en fabrikanten van gedroogd vleesch met het meeste gemak voor dat van zeeroover. Het was wel een internationaal gezelschap, dat zich daar op Tortuga verzamelde. Onder de Hollanders, die daar wel kwamen, zijn er een paar, die ons door toevallige omstandigheden wat beter bekend zijn, dan het gros. Een hunner had n.l. wat hoogere aspiraties dan het zeerooversbedrijf en heeft zijne avonturen en die zijner makkers beschreven in een boekje, dat in verschillende talen vertaald is en daardoor aan de bedrijven der piraten algemeene bekendheid verschafte. Deze schrijver-zeeroover was Alexander Olivier Exquemelings. Zijn naam klinkt niet zeer Hollandsch, maar die zal in zijn Spaansch-Fransche omgeving vermoedelijk wel verbasterd zijn. Volgens sommige opgaven was hij een Vlaming; meer waarschijnlijk lijkt het echter, dat hij van Hollandsche afkomst was. In zijn tijd toch waren het vooral Hollanders en Zeeuwen, die naar de West gingen en bovendien werd het bovenvermelde boekje in 1678 uitgegeven door Jan van Hoorn, Boeckverkooper over 't Oude Heeren-Logement te Amsterdam. De uitgever, die zich zelf Jan Claesz. ten Hoorn noemt, voorzag het werkje van een uitvoerige voorrede, waarin hij o. a. vermeldt, dat de Spaansche koning in dien tijd nog slechts betrekkelijk gering voordeel van zijne Amerikaansche bezittingen had, in deze bewoordingen: „der landen verafgelegentheydt en de menighte der bedienaers verdunnen deselve soodanig, dat nauwelijx het tiende deel aen den rechten Heer komt." En ook de zeeroovers droegen daartoe niet weinig bij, zooals uit het boekje blijkt. Dit draagt den wijdloopigen titel: „De Americaensche Zee-Roovers. Behelsende een pertinente en waerach- 
tige Beschrijving van alle de voornaemste Roverijen en onmenschelijke wreedheden, die de Engelse en Franse Rovers, tegens de Spanjaerden in America, gepleeght hebben, door A. O. Exquemelings, Die zelf alle dese Roverijen, door noodt bijgewoont heeft". Eene vertaling ervan in het Fransch, waar de schrijver vermeld wordt onder den naam A. O. Oexmelin zag in 1686 te Parijs het licht. Deze draagt tot titel: „Histoire des aventuriers, qui se sont signalés dans les Indes avec la vie, les moeurs et les coûtumes des boucaniers." De schrijver begint het relaas zijner wederwaardigheden met te verhalen, hoe hij noodgedwongen het zeerooversbedrijf ter hand moest nemen. Met een schip der W. I. C. vertrok hij 2 Mei 1666 naar Tortuga, om daar in den handel werkzaam te zijn. Tortuga was toen reeds geruimen tijd in Fransch bezit en werd, voor zoover daarvan in die vrijwel bandelooze samenleving sprake kon zijn, bestuurd door den Gouverneur van het Fransche gedeelte van het vroegere Hispaniola, dat toen den naam van St. Domingo droeg. Deze gouverneur, Bertrand d'Ogéron de la Bouère was een der vele Fransche avonturiers, die door de West aangetrokken werden. Hij had het reeds gebracht tot kapitein bij de marine, toen hij in 1656 besloot, op avontuur naar Amerika te trekken. Eerst begaf hij zich naar Martinique lag daar echter al spoedig met den gouverneur overhoop en begaf zich toen naar St. Domingo. Op die reis leed hij schipbreuk, bracht er het leven af en hield geruimen tijd verblijf bij de boekaniers tot hij een gelegenheid wist te vinden om naar Frankrijk terug te keeren. Daar werd hij door de inmiddels opgerichte Compagnie des Indes Orientales in 1665 benoemd tot gouverneur van St. Domingo. Hij trachtte zooveel mogelijk den uitvoer naar Frankrijk te bevorderen en tegelijkertijd den handel zijner kolonie met de Spaansche te ontwikkelen. Wel was aan Spaansche koloniën alle handelsverkeer met andere natiën herhaaldelijk verboden, maar Spanje was ver, de ambtenaren waren alles behalve onomkoopbaar en daardoor bloeide in de 17e eeuw een levendige smokkelhandel in de West welig op. Voor den Hollandschen handel was toen 
gen. De laatste benaming, misschien een verbastering van het Engelsche freebooter, Hollandsch vrijbuiter, misschien ook wel afgeleid van het Hollandsche woord vlieboot, Engelsch flyboat, wees meer in het bijzonder op hunne werkzaamheid, als zeeroovers. Veel verschil was er in den grond der zaak niet tusschen boekaniers en flibustiers; zooals boven reeds vermeld werd, verwisselden, zoo zij daar lust toe gevoelden, de boekaniers hun beroep van jagers en fabrikanten van gedroogd vleesch met het meeste gemak voor dat van zeeroover. Het was wel een internationaal gezelschap, dat zich daar op Tortuga verzamelde. Onder de Hollanders, die daar wel kwamen, zijn er een paar, die ons door toevallige omstandigheden wat beter bekend zijn, dan het gros. Een hunner had n.l. wat hoogere aspiraties dan het zeerooversbedrijf en heeft zijne avonturen en die zijner makkers beschreven in een boekje, dat in verschillende talen vertaald is en daardoor aan de bedrijven der piraten algemeene bekendheid verschafte. Deze schrijver-zeeroover was Alexander Olivier Exquemelings. Zijn naam klinkt niet zeer Hollandsch, maar die zal in zijn Spaansch-Fransche omgeving vermoedelijk wel verbasterd zijn. Volgens sommige opgaven was hij een Vlaming; meer waarschijnlijk lijkt het echter, dat hij van Hollandsche afkomst was. In zijn tijd toch waren het vooral Hollanders en Zeeuwen, die naar de West gingen en bovendien werd het bovenvermelde boekje in 1678 uitgegeven door Jan van Hoorn, Boeckverkooper over 't Oude Heeren-Logement te Amsterdam. De uitgever, die zich zelf Jan Claesz. ten Hoorn noemt, voorzag het werkje van een uitvoerige voorrede, waarin hij o. a. vermeldt, dat de Spaansche koning in dien tijd nog slechts betrekkelijk gering voordeel van zijne Amerikaansche bezittingen had, in deze bewoordingen: „der landen verafgelegentheydt en de menighte der bedienaers verdunnen deselve soodanig, dat nauwelijx het tiende deel aen den rechten Heer komt." En ook de zeeroovers droegen daartoe niet weinig bij, zooals uit het boekje blijkt. Dit draagt den wijdloopigen titel: „De Americaensche Zee-Roovers. Behelsende een pertinente en waerach- 
tige Beschrijving van alle de voornaemste Roverijen en onmenschelijke wreedheden, die de Engelse en Franse Rovers, tegens de Spanjaerden in America, gepleeght hebben, door A. O. Exquemelings, Die zelf alle dese Roverijen, door noodt bijgewoont heeft"'. Eene vertaling ervan in het Fransch, waar de schrijver vermeld wordt onder den naam A. O. Oexmelin zag in 1686 te Parijs het licht. Deze draagt tot titel: „Histoire des aventuriers, qui se sont signalés dans les Indes avec la vie, les moeurs et les coûtumes des boucaniers." De schrijver begint het relaas zijner wederwaardigheden met te verhalen, hoe hij noodgedwongen het zeerooversbedrijf ter hand moest nemen. Met een schip der W. I. C. vertrok hij 2 Mei 1666 naar Tortuga, om daar in den handel werkzaam te zijn. Tortuga was toen reeds geruimen tijd in Fransch bezit en werd, voor zoover daarvan in die vrijwel bandelooze samenleving sprake kon zijn, bestuurd door den Gouverneur van het Fransche gedeelte van het vroegere Hispaniola, dat toen den naam van St. Domingo droeg. Deze gouverneur, Bertrand d'Ogéron de la Bouère was een der vele Fransche avonturiers, die door de West aangetrokken werden. Hij had het reeds gebracht tot kapitein bij de marine, toen hij in 1656 besloot, op avontuur naar Amerika te trekken. Eerst begaf hij zich naar Martinique lag daar echter al spoedig met den gouverneur overhoop en begaf zich toen naar St. Domingo. Op die reis leed hij schipbreuk, bracht er het leven af en hield geruimen tijd verblijf bij de boekaniers tot hij een gelegenheid wist te vinden om naar Frankrijk terug te keeren. Daar werd hij door de inmiddels opgerichte Compagnie des Indes Orientales in 1665 benoemd tot gouverneur van St. Domingo. Hij trachtte zooveel mogelijk den uitvoer naar Frankrijk te bevorderen en tegelijkertijd den handel zijner kolonie met de Spaansche te ontwikkelen. Wel was aan Spaansche koloniën alle handelsverkeer met andere natiën herhaaldelijk verboden, maar Spanje was ver, de ambtenaren waren alles behalve onomkoopbaar en daardoor bloeide in de 17e eeuw een levendige smokkelhandel in de West welig op. Voor den Hollandschen handel was toen 
Curaçao het gunstig gelegen middelpunt en vaak genoten Hollandsche handelaars, zoowel in Spaansche als Fransche koloniën de voorkeur boven die van eigen nationaliteit. Gouverneur Ogéron wilde nu den handel van zijn kolonie organiseeren ,,gelyck de Hollanders in Curassouw doen". Hierin slaagde hij echter evenmin als in zijn pogingen om den uitvoer vooral met Fransche schepen te doen plaats hebben. Exquemelings vermeldt, dat in 1669 twee Hollandsche schepen Tortuga aandeden en weldra volledige lading hadden, terwijl eenige Fransche, die er ook waren, half geladen onder zeil moesten gaan. Het was dan ook niet te verwonderen, dat Ogéron begeerig uitzag naar een gelegenheid, om die lastige concurrenten zoo mogelijk te verdrijven. De oorlog van 1672 verschafte hem die. Exquemelings verhaalt dit als volgt: In het Jaer sestien hondert drie en seventigh hadden d'Ingeseetenen der Eylanden / behoorende onder den Koningh van Vranckryck / seeckere macht bij een gebracht / om de plaetsen / onder 't gebied der Heeren Staten van Hollandt zynde / te veroveren en te ruineeren ...........

De Gouverneur van Tortuga was selver op een Oorlogschip gegaen / dat doemaels op de Reede lagh / met vier a vijf hondert man die boschloopers / of Boekaniers genoemt worden / die op het Eylandt Espanjola zyn / met voorneemen om zich te conjugeeren met de Generael van de Franse / om mede na Curaçao te gaen; maer hy wierd van zijn desseyn versteecken / door een ongeluck dat hem overquam aen de zuydtkant van het Eyland St. Juan de Porto Rico / alwaer hy by nacht door een swaere storm aangetast wierdt / en syn Schip op de klippen dreef.

Bij deze onderneming tegen Curaçao, waarvan Hamelberg de verdere mislukking vermeldt, schijnt Exquemelings niet tegenwoordig geweest te zijn. Hij had echter inmiddels op Tortuga en St. Domingo allerlei minder aangename ervaringen opgedaan. Immigranten werden daar blijkbaar onder onware voorspiegelingen door de Franschen heengelokt en eenmaal aangekomen, als slaven behandeld. Ook Engelschen, die er eveneens waren, hielden zich met dergelijke praktijken op. Debiteurs, die 
hunne schulden niet konden betalen, werden in menigte naar de West gedeporteerd, zelfs als het bedrag van de schuld niet belangrijk was, ook al om in het gebrek aan werkkrachten te voorzien. Exquemelings beweert, dat dit geschiedde overeenkomstig een Engelsche wet, die voorschreef, dat wie 25 /. schuldig was en niet kon betalen, als slaaf verkocht werd en gedurende 1 jaar en 6 maanden zijn meester moest dienen. Hijzelf, ofschoon in dienst van een Fransche matschappij, verloor ook eenigen tijd zijn vrijheid. De zaken der Fransche Compagnie n.l. gingen alles behalve naarwenschwaarom zijopgeheven en door een nieuwe vervangen werd. In verband met zijne onderhandelingen, om door deze als Gouverneur overgenomen te worden, begaf Ogéron zich naar Frankrijk, het beheer der zaken tijdelijk overlatende aan den onder-gouverneur, dien Exquemelings ,den snoodsten schelm” noemt. De tweede compagnie had al even min voorspoed, als haar voorgangster, o. a. door het eigenaardige slag clienten, waarmede zij zaken moest doen. Boekaniers en flibustiers b.v. wilden wel waren van hare magazijnen betrekken en die ook wel betalen, ....als zij geld hadden. Maar, als er geruimen tijd niets te rooven geweest was, waren zij court d'argent en eischten dan waren op crediet. Dit werd in te ruime mate verleend, betalingen kwamen zeer onregelmatig binnen en de tweede compagnie vond het raadzaam, de zaken althans op Tortuga maar op te geven. De voorraden werden uitverkocht en in dien uitverkoop werden eenige bedienden, die vernoedelijk ook nog in het krijt stonden, meteen begrepen. Exquemelings behoorde daar ook toe en hij was al bijzonder onfortuinig, daar hij juist in handen viel van den bovengenoemden ,snoodsten schelm”, den onder-gouverneur. Deze liet hem zwaar werken en van tijd tot tijd aan den lijve afstraffen, waardoor hij ten slotte zwaar ziek werd. Voor 70 stukken van achten werd hij toen overgedaan aan een chirurgijn en, zooals hij zelf vermeldt, bestond zijn geheele bezitting nog in „één oudt hemdt en een onderbroeck". Bij zijn nieuwen meester, die hem wat menschelijker behandelde, bleef hij een jaar en deze stelde hem voor 150 stukken van achten 
daarna in vrijheid. Wel vrij man, maar zonder eenig middel van bestaan, begaf gij zich toen „door noodt” onder de zeeroovers en deelde hunne avonturen tot 1672, waarna hij blijkbaar naar Holland wist terug te keeren.

Zijn boekje doet ons kennis maken met verschillende hoofden der vrijbuiters, van wie de Engelschman Henry Morgan wel de meest succesvolle loopbaan had, daar hij zijn levensloop eindigde, als Sir Henry Morgan, Gouverneur van Jamaica. Hij was in 1635 geboren te Llanchynny in Wales en werd als jongeling in Bristol op een schip gelokt en naar Barbados vervoerd, waar hij met anderen verkocht werd. Dit ontvoeren van jongelieden kwam destijds in Engeland zeer veel voor. Het was bekend onder den naam van ,,spiriting” en vooral de havens van Bristol en van Londen waren ervoor berucht, dat van daar menigten van vagebonden en geronselden, met of tegen hun zin, naar de West vervoerd werden. Herhaaldelijk, o.a. in 1664 en 1668 werd dit verboden, echter met zoo weinig succes, dat in 1670 een wet moest uitgevaardigd worden, waarbij op menschenroof de doodstraf gesteld en de bijstand van een geestelijke aan den veroordeelde in zijn laatste oogenblikken ontzegd werd.

Morgan kwam natuurlijk, evenals zoovelen, spoedig in betrekking tot de zeeroovers en maakte als een der hunnen weldra zijn naam geducht in de Westindische wateren, eerst als onderbevelhebber van een anderen Engelschman, Edward Mansfield. Door de verovering van Jamaica in 1655 waren naast Franschen en Hollanders de Engelschen ook al zeer gevaarlijke concurrenten voor de Spanjaarden geworden. Die verovering van Jamaica was al met het zelfde sans-gène in zijn werk gegaan, als waarmede destijds de zaken in de West gewoonlijk behandeld werden. Verschillende eilanden van de Kleine Antillen waren reeds tijdelijk, of voor goed door Engelschen bezet, b.v. Nevis, Barbados e. a. en, zooals bekend is, was Lord Willoughby er zelfs in geslaagd, een kolonie in Suriname te grondvesten. Herhaaldelijk kwamen echter bij het bestuur van het Engelsche Gemeenebest klachten in over moeilijkheden, die de Spanjaarden, zeer ver- 
klaarbaar, niet ophielden, Engelschen koopvaarders en planters in den weg te leggen. Cromwell gaf hun daarom verlof ,to right themselves" en zond een vloot uit onder William Penn, als admiraal met een inderhaast samengeraapt landingsleger onder commando van Robert Venables. Deze laatste had in Ierland onder den Protector gediend en aan de beruchte verwoesting van Drogheda een belangrijk aandeel genomen. Zijn opdracht was „to gain an interest in that part of the West Indies in possession of the Spaniards". De aanvoerder was dus geheel vrij in de keuze van het punt, waar hij zijn aanval zou doen; hij had alleen overleg te plegen met twee gedeputeerden, die medegezonden waren. Een aanval op Hispaniola mislukte. Venables, die wegens deze mislukking in den Tower werd gevangen gezet, beklaagde zich bitter over het slechte gehalte zijner troepen en over het gemis aan overeenstemming onder de aanvoerders. De vloot zeilde, toen men van Hispaniola moest terugtrekken, naar Jamaica, dat zonder veel moeite veroverd werd en sedert in handen der Engelschen bleef, onder wier bestuur het een der bloeiendste Westindische koloniën werd; eerst in 1670 legde Spanje zich bij het verlies er van neer.

Een der eerste Engelsche gouverneurs, Sir Thomas Modiford maakte gaarne gebruik van de diensten, die vrijbuiters, als Mansfield en anderen konden bewijzen tegen de Spanjaarden en tegen de Fransche en vooral de Hollandsche mededingers. Den laatsten werd het voor den smokkelhandel zoo gunstig gelegen eiland Curaçao ook door de Engelschen misgund. Vier jaar voor den boven vermelden, mislukten Franschen aanslag op het eiland was een troep van 600 boekaniers onder Mansfield, met Morgan als onderbevelhebber, uitgezeild, om „Curaçao and the Goat-Islands of Aruba and Banari” te veroveren. Volgens Hamelberg mislukte deze onderneming echter door oneenigheid onder de deelnemers, waarna ieder op eigen gelegenheid op roof uitging. Bij een dezer tochten werd het eiland Santa Catalina, vanwaar Panamá met succes bedreigd kon worden, door Mansfield en Morgan veroverd. De eerste viel kort daarop in handen der Span- 
jaarden en Morgan werd nu het erkende hoofd der vrijbuiters. Als zoodanig maakte hij zijn naam geducht in de geheele West. Bij eenige zijner tochten, o.a. bij den aanval op Puerta-Bello in 1668 en bij dien op Panamá was Exquemelings tegenwoordig, bij den laatsten ook wellicht de Hollander Jan Erasmus Reyningh. Volgens Hamelberg was deze het misschien, die de huizen bij het fort van Chagres in brand schoot. Exquemelings verhaalt dit voorval als volgt: „Een van de Rovers wierd een pijl door syn schouder geschooten; hy trock deselve met een furie door de schouder heen / en nam een party Catoen / dat hy in syn sack hadt / dee dat aen de pyl vast / en stack hetselve in de brandt; doen 't selve wel in de brandt was / stack hy de pijl in syn Roer / en schoot die op eenighe huysen in 't Kasteel / die met palmiste bladeren bedeckt waren: d'andere Rovers dit siende / begonnen het selve oock te doen. Eyndelyck geluckte haer pracktijck / soo dat de daecken van twee à drie huysen in de brand raeckten."

Deze onderneming tegen Panamá werd, daar de boekaniers toen een hoofd hadden, dat gehoorzaamheid wist af te dwingen, met succes bekroond. Evenals bij den beraamden aanval op Curaçao in 1666 was echter het gemis aan discipline onder de bandelooze gasten vaak oorzaak, dat niet meer dan een zeer tijdelijk voordeel behaald werd Boekaniers waren te gebruiken als hulptroepen, zelfstandig konden zij niet in onderling verband optreden. Morgan had dan ook, om hunne samenwerking te behouden, voor den aanval op Panamá heel wat toezeggingen moeten doen en naar Exquemelings verhaalt, moest iedere deelnemer vooraf getuigen, dat hij het eens was met de gemaakte bepalingen, die vooral betrekking hadden op belooning voor buitengewone dapperheid. Hij vermeldt daaromtrent: „Daer na wierd'er een vergeldinge toegeleydt voor die geenen / die eenighe genereuse actie souden doen tot afbreuck van den vyandt / als namelijck voor die 't eerste de Vlagh van een Fort soude strijcken / ende d'Engelsche vlagh daer op setten / die soude buyten syn deelinghe noch vijftigh stucken van achten genieten; die 
een gevangen nam / en aenbrocht in tijdt van noodt / soude buyten syn deelinge ghenieten twee hondert stucken van achten; de Granadiers / die gestelt waren om granaten in een kasteel te werpen / souden voor yder granaed / diese in het Kasteel geworpen hebben / buyten haer part / genieten vijf stucken van achten."

Behalve de bijzondere bepalingen, die voor deze gelegenheid werden vastgesteld, was er een vrijwel algemeen erkend soort reglement, aan de bepalingen waarvan de vrijbuiters zich onderwierpen. Zoo was er een eigenaardige gewoonte, waaraan zij hun naam van „Brethren of the Coast", zooals zij zichzelf bij voorkeur noemden te danken hadden, n.l., dat ieder een zijner makkers als wapenbroeder koos, met wien hij in den strijd samenwerkte en van wien hij alles erfde, in geval hij sneuvelde of op andere wijze om het leven kwam. De meeste bepalingen hadden betrekking op de wijze van verdeeling van de buit en op schadeloosstelling voor verminkingen. „Buyten syn part” doelt dan ook op het deel, dat ieder volgens algemeene gewoonte van het geroofde toekwam. Die gewoonte schreef o. a. het volgende voor: De behaalde buit werd gelijkelijk onder de deelnemers aan iedere expeditie verdeeld. Vooraf werden er echter bijzondere belooningen toegekend en wel aan den kapitein van een schip 4 à 5 matrozendeelen voor het gebruik van zijn schip en bovendien nog 2 deelen voor hemzelf. Een jager kreeg vooraf 200 srukken van achten, een timmerman 100 à 150, een chirurgijn 200 à 250 naar gelang van de grootte van het schip enz. Verminkten werden daarna schadeloos gesteld. Het verlies van den rechterarm werd vergoed met 600 stukken van achten of 6 slaven, dat van den linkerarm met 500 stukken van achten of 5 slaven, en zoo naar gelang van het belang van het verloren of onbruikbaar geworden lichaamsdeel.

Voor Morgan, den aanvoerder bij de verovering en plundering van Panamá had Exquemelings, hoewel hij de wreedheden der flibustiers herhaaldelijk afkeurt, wel respect, waartoe wel zal bijgedragen hebben, dat deze later een voornaam heer werd; minder goed is hij echter te 
spreken over zijn eigen landgenoot Roc, die algemeen gevreesd werd, wat niet te verwonderen is, als men weet, dat deze de liefhebberij had, als hij eens op Jamaica of elders ging passagieren, met een scherp geslepen hartsvanger in den arm te wandelen, waarmede hij iedereen te lijf ging, die hem op een wijze aankeek, die niet in zijn smaak viel. Roc was een Groninger van geboorte; hij was reeds als kind met zijne ouders naar Brazilië gegaan en was dan ook algemeen bekend onder den naam van „Roc de Braziliaan”. Nadat Brazilië weer in handen der Portugeezen gekomen was, zwierf hij van eiland tot eiland en raakte ten slotte op een vrijbuitersschip verzeild. Bij gelegenheid eener muiterij werd hij door de bemanning daarvan als aanvoerder gekozen en werkte geruimen tijd met Reyningh samen, die aanvankelijk onder hem diende.

Ten slotte werd hij gevangen genomen en op een Spaansche galei naar Spanje gezonden; op reis deed hij dienst als visscher en wist daarmede 500 stukken van achten te verdienen, welke som hem in staat stelde na aankomst in Spanje uit zijne gevangenis te ontvluchten, zich naar Jamaica te begeven en zich weder bij zijn makkers te voegen.

De meesten daarvan zijn alleen bekend onder hunne bijnamen. Onder de Franschen had men b.v. François Lolonais, die dien naam te danken had aan zijn geboorteplaats, les Sables d'Olonne. Hij werkte geruimen tijd samen met een aanvoerder uit het Noorden van Spanje, Miguel el Basco, die na eenigen tijd voldoende geroofd had om zich bij wijze van een rentenier op Tortuga te vestigen. Een beraamde aanval op Maracaibo leek hem echter verleidelijk genoeg, om hem uit zijn „otium cum dignitate" te lokken en er een belangrijk aandeel aan te nemen. Lolonais schijnt nog een graadje wreeder dan Miguel, Roc en anderen geweest te zijn, hij werd bij gelegenheid van een rooftocht in Nicaragua door een Indiaan vermoord. Een der illustraties, die in het werkje van Exquemelings voorkomen, vertoont hem bij een gevecht voor de muren van Maracaibo, terwijl hij in het uitgesneden hart van een gesneuvelden Spanjaard bijt. De 
schrijver-vrijbuiter heeft van hem een blijkbaren afkeer, die volkomen gerechtvaardigd schijnt. $\mathrm{Na}$ zijn dood in Nicaragua vermeld te hebben, voegt hij erbij. „Dit is het endt van een mensch, die soo veel onschuldigh bloedt gestort en soo veel gruwelen bedreven heeft."

Tijdens den oorlog van 1672 nog traden de boekaniers op verschillende plaatsen zeer actief op en aan verschillende ondernemingen tijdens den negenjarigen oorlog namen zij eveneens deel. In het laatste deel van de 17e eeuw waren de toestanden in de West echter zoodanig veranderd, dat van verschillende zijden pogingen gedaan werden, om hun zelfstandig optreden te beperken en hen aan zekere tucht te gewennen. Vooral van Engelsche zijde werd dit het eerst met eenig succes beproefd. Dit laatste was vooral te danken aan de omstandigheid, dat Henry Morgan door zijn vroegere kameraden niet meer vertrouwd werd en hij het voorzichtiger oordeelde, maar met hen te breken en de zijde van het Engelsche gezag te kiezen. Zijn tocht naar Panamá was zijn laatste flibustiersbedrijf. Daarbij had hij de vijandelijkheden tegen Spanje te lang voortgezet, zelfs nog nadat inmiddels vrede tusschen Engeland en Spanje gesloten was. Hiervoor werd hij naar Engeland ter verantwoording geroepen, doch wist zich door omkooping van zijn voornaamste aanklagers zoo geheel vrij te pleiten, dat hij door $\mathrm{Ka}$ rel II zelfs tot knight verheven werd. Voortaan komt hij dan ook voor als Sir Henry Morgan en bekleedde tot 1688 het ambt van Gouverneur van Jamaica.

Sir Henry Morgan, de vroegere vrijbuiter, thans handhaver van het Britsche gezag, verzette zich voortaan met kracht tegen de buitensporigheden zijner vroegere makkers; hunne diensten werden alleen dan aanvaard, als zij zich eerst van kaperbrieven voorzien hadden, waarmede men trouwens zoowel van Britsche, als van Fransche en Spaansche zijde vrijgevig genoeg was. De hiervoor vermelde Jan Erasmus Reyningh was b.v. achtereenvolgens als kaper in dienst van den Engelschen Gouverneur van Jamaica, verkreeg daarop een kaperbrief van Spaansche zijde om op Engelsche schepen jacht te maken en had in 
1673 van den Gouverneur van Curaçao, Jan Doncker, zulk een document verkregen, dat hem recht gaf, op Engelsche en Fransche schepen te kruisen.

In het laatste gedeelte van de 17 e eeuw deden de boekaniers vooral dienst als hulptroepen bij gelegenheid van Fransche rooftochten in de West. Bij zijn mislukten aanval op Curaçao in 1678 b.v. had D'Estrées zich de medewerking verzekerd van 15 kaperschepen, waarvan hij, ten einde ze beter onder controle te kunnen houden, de bemanningen gedeeltelijk over zijn oorlogschepen had verdeeld, om hunne plaatsen door andere matrozen te doen innemen. Zulke hulptroepen werden in dien tijd geregeld gerecruteerd op St. Domingo. Daar had de Compagnie du Sénégal een kantoor voor den slavenhandel, waarvan destijds de, in de Surinaamsche geschiedenis bekende Jean-Baptiste Ducasse, een Béarnees, Directeur was. Zijn betrekkingen tot den negerhandel en zijn nauwkeurige bekendheid met de zeden en gewoonten der boekaniers en flibustiers maakten, dat hij een belangrijke rol kon spelen in de krijgsbedrijven in de West. Waren de Fransche legers onder het energieke beheer van Louvois, als minister van oorlog, onder de beste van dien tijd te rangschikken, met de marine was het minder goed gesteld. Veel animo, om bij haar te dienen, bestond er over het algemeen bij de Fransche zeelieden niet; kaapvaart en van tijd tot tijd zeeroof trok hen meer aan. Niet zelden vindt men de Franschen in de 17e eeuw en later dan ook aangeduid als ,la nation pirate”. Met het verkrijgen van zeeofficieren had men minder moeite dan met het volledig maken der bemanningen; officieren der koopvaardij en van het leger en vooral Maltheser ridders stelden zich daar voor gaarne beschikbaar en het commando over een eskader of vloot werd niet zelden toevertrouwd aan een generaal, die dan den titel van maarschalk verkreeg. Dat geschiedde b.v. met D'Estrées en met De Tourville. Het gelukte eigenlijk eerst tusschen 1680 en '90, eskaders van voldoende sterkte te vormen, waarvan 50 à 70 schepen voor de koloniën beschikbaar gesteld konden worden. Medewerking van particuliere reederijen was echter hier- 
toe geruimen tijd noodig, zoowel in Frankrijk zelf, als in de koloniën.

Iemand, als Ducasse, die zoo noodig bij roof- en verwoestings-expedities in de West hulp kon verleenen, of deze zelfstandig kon organiseeren, was dan ook voor de regeering veel waard. Lodewijk XIV verleende hem den rang van „capitaine de vaisseau” en in 1689 kreeg hij opdracht, van St. Domingo naar Cayenne te gaan en vandaar te trachten, de kolonie Suriname te verwoesten en buit en voorraden, die hij daar vermeesterde, naar Cayenne te vervoeren. Het is bekend, dat door den dapperen tegenstand, dien hij bij het opvaren van de rivier ondervond, gedeeltelijk onder leiding van François van Aerssen, deze onderneming mislukte. Bij een tweeden raid tijdens den negenjarigen oorlog in de Westindische wateren, ditmaal tegen de Spaansche koloniën gericht, werd wederom de hulp van Ducasse en zijn vrijbuiters ingeroepen. Dat was bij den aanval van De Pointis op Carthagena, die beter dan die van Ducasse op Suriname gelukte, doch waarbij het duidelijk werd, dat door de officieele marine boekaniers wel als bruikbare, maar toch als minderwaardige hulptroepen beschouwd werden. In een verslag, omtrent dezen tocht, dat De Pointis in 1698 publiceerde onder den titel „Relation de l'expédition de Carthagène”, verhaalt hij, dat de boekaniers hoogst ontevreden waren over de wijze, waarop zij behandeld werden, waartoe zij, van hun standpunt geredeneerd, ook alle reden hadden. Boekaniers en flibustiers waren van oudsher gewoon geweest, er op eigen gelegenheid op uit te trekken en handelden met den behaalden buit, zooals hunne gewoonten dat voorschreven, maar thans werd hun hulp eenvoudig gerequireerd en hadden zij zich te onderwerpen aan een commandant, die alles behalve gemakkelijk was.

Jean-Bernard, baron de Pointis, had reeds een belangrijke loopbaan achter zich. Nadat hij zich onderscheiden had in een tocht tegen de Barbarijsche zeeroovers en onder Tourville aan verschillende zeeslagen, o.a. aan dien van Beachy Head, had deelgenomen, was op zijn voorstel, gedeeltelijk door de kroon, gedeeltelijk door 
particuliere reederijen een vloot bijeengebracht voor een tocht naar de West. Ducasse kreeg uit Frankrijk bevel, zooveel soldaten, als de veiligheid der kolonie veroorloofde, en verder flibustiers, te zamen 1200 man, als hulptroepen gereed te houden. Al spoedig werd hem duidelijk, dat noch hijzelf, noch zijn manschappen, veel genoegen aan hunne medewerking zouden beleven. Ducasse had, ofschoon Gouverneur van het Fransche gedeelte van St. Domingo, slechts den rang van capitaine de vaisseau en De Pointis bleek ongenegen, hem als van hoogeren rang te beschouwen en achtte eerbewijzen, als een Gouverneur toekwamen, voor een minderen in rang, dan hijzelf was, overbodig. Hij weigerde zelfs hem te erkennen als commandant van een zelfstandig hulpcorps. En hiervan was hij niet af te brengen; trouwens zijn reputatie was: „Il était capable de former un grand dessein en de rien épargner pour le faire réussir." Gespaard heeft hij althans Ducasse en dien boekaniers niet. Omtrent de laatsten verklaarde hij kortaf: „Daar ik hen beschouwde als onderdanen van $Z$. M., die de Gouverneur te mijner beschikking moest stellen, deelde ik hun mede, dat zij in mij een commandant zouden vinden en niet iemand, die deel nam in hunne ondernemingen." De verhouding was dus afgebakend; Ducasse en de vrijbuiters hadden eenvoudig te gehoorzamen. Vooral den eerste gaf dat heel wat moeilijkheden. De vloot van De Pointis kwam later aan, dan verwacht werd, wat al dadelijk onaangenaamheden met de flibustiers veroorzaakte. Deze toch waren gewoon, in verband met de weersgesteldheid en de heerschende winden, in het begin van het jaar uit te zeilen en moesten nu werkeloos blijven liggen. Met groote moeite wist Ducasse hen te bewegen, tot half Februari te wachten, het tijdstip, waarop de vloot verwacht werd. Deze kwam echter pas begin Maart bij Kaap Tiburon in het gezicht. Na haar aankomst stelde de Gouverneur Ducasse voor, een aanval te doen op de stad Santo Domingo, die nog Spaansch was, en welker vermeestering in het belang der Fransche kolonie op het eiland zou geweest zijn. Du Pointis besliste echter, daar elders meer buit te behalen zou zijn en 
de reederijen, die schepen medegegeven hadden, belangrijke profijten verwachtten, dat men zou trachten, de stad Carthagena te vermeesteren. Daarheen begaf de expeditie zich dan ook en al dadelijk werd den boekaniers het gevaarlijkste werk opgedragen, n.l. de inneming van een op een heuvel gelegen kerk, waar een deel der Spaansche bezetting zich verschanst had en vanwaar de stad onder vuur genomen kon worden. Zij slaagden in de uitvoering van hun opdracht en deden dus hun reputatie eer aan. Want, toen De Pointis er tegenover Ducasse aanmerking op maakte, dat deze niet het geëischte aantal van 1200 nam beschikbaar had, had deze verklaard, dat zulks hem niet mogelijk geweest was, maar, dat iedere man ongetwijfeld wonderen zou verrichten. Voor die wonderen werden zij echter slecht beloond, want, toen kort daarna de stad was ingenomen, werd wel Ducasse tot Gouverneur benoemd, maar zijne boekaniers werden uitgezonden om een aanval van 10.000 Indianen af te slaan, die intusschen alleen door De Pointis gefantaseerd was, om een voorwendsel te hebben om hen weg te zenden. Tijdens hun afwezigheid werd de buit in veiligheid aan boord der schepen gebracht; 110 muilezels beladen met goud en zilver brachten in vier dagen voor een waarde van 8 à 9 millioen livres aan boord der Fransche schepen. Veel was bovendien ook nog, vooral door de officieren verduisterd, door sommigen tot een bedrag van 10.000 kronen. Ducasse schatte dan ook de totale buit op een waarde van 20 millioen (vermoedelijk livres), aan goud en zilver, waarbij dan nog de waarde der koopmansgoederen kwam. Officieren en reeders konden dus tevreden zijn.

Groot was echter de woede der boekaniers, die bij hun terugkomst bemerkten, dat hun het, volgens hunne opvattingen, gerechte aandeel ontgaan was. Hun plan, om het schip van De Pointis, de Sceptre, een fregat met 84 stukken geschut, aan te vallen, was onuitvoerbaar, daar de vrijbuitersschepen te klein waren en een protest van Ducasse had geen uitwerking. De commandant antwoordde eenvoudig: „De boekaniers zijn groote schurken en verdienden opgehangen te worden." Ten einde raad be- 
sloten deze daarom, Carthagena nog maar eens te plunderen en weg te voeren, wat nog overgebleven was.

Dit was de laatste maal, dat gebruik gemaakt werd van de hulp der vrijbuiters in de West. Zooals boven gezegd werd, begon men in Frankrijk, evenals in Engeland in te zien, dat zij niet alleen voor de Spanjaarden, maar ook voor de eigen koopvaardijschepen een gevaar opleverden. $\mathrm{Na}$ den vrede van Rijswijk is dan ook hun rol uitgespeeld. Voor de meesten werd het zeerooversbedrijf te gevaarlijk ten gevolge van het scherpe politie-toezicht in de Westindische wateren en noodgedwongen verwisselden velen het voor dat van visscher of planter. Alleen van tijd tot tijd, als de verleiding te sterk werd, konden enkelen wel eens geen weerstand bieden aan de verlokkingen van de vrije zee. Soms waren dat kapiteins, die als kaper uitgezeild, zich aan zeerooverij te buiten gingen. Dat deed b.v. de beruchte Captain Kidd, de held van vele romans en balladen. Weliswaar bedreef hij zijne meeste euveldaden niet in de Westindische wateren, maar volledigheidshalve moge het voornaamste uit zijn avontuurlijk bestaan hier nog ten slotte vermeld worden.

Robert Kidd was in New-York geboren en was in den negenjarigen oorlog belast met het commando over een Engelsch kaperschip. Hij genoot het volle vertrouwen van den toenmaligen Gouverneur van New-York, Sir George Bellemont. Door particuliere reeders werd in dien tijd een soort naamlooze vennootschap gesticht, die zich ten doel stelde, schepen uit te rusten, om wreedheid tegenover de bemanning van prijsgemaakte koopvaarders te beletten en tevens zeerooverij tegen te gaan. De Gouverneur was een der voornaamste aandeelhouders en op zijn aanbeveling verkreeg Kidd naast zijn kaperbrief een opdracht, jacht te maken op zeeroovers en buitgemaakte schepen in de haven van New-York op te brengen. De opbrengst van de buit zou voor het grootste deel ten voordeele van de aandeelhouders komen, nadat eerst 1/10 deel aan den Koning was afgedragen. Kidd zeilde uit met zijn schip, de Adventure, en had spoedig succes door het nemen van een Fransch vaartuig, dat hij over eenkomstig 
zijn opdracht, naar New-York voerde. Daarna ging hij ertoe over, zijne bemanning belangrijk uit te breiden, zoodat hij, opnieuw uitgezeild ongeveer 150 uitstekende zeelieden onder zijn bevelen had. Hij bleef toen niet in de Amerikaansche wateren kruisen, maar maakte op zee zijn voornemen bekend, de kaperij eraan te geven en ten eigen profijte op zeeroof uit te gaan. Daartoe richtte hij den steven naar den Indischen Oceaan. Een der manschappen, die er niet volkomen mede instemde, sloeg hij met een emmer, die toevallig onder zijn bereik was, de hersens in, na welk overtuigend argument de rest, die er trouwens niet afkeerig van was, de nieuwe loopbaan te kiezen, geen verdere bezwaren opperde. Kidd maakte toen maanden lang, eenigen tijd zelfs in samenwerking met den beruchten zeeroover Culford, de Roode Zee en den Indischen Oceaan onveilig. Fransche, Hollandsche, noch Engelsche koopvaarders waren voor hem veilig. Toen zijn buit groot genoeg was, besloot hij de thuisreis te aanvaarden. Hij hoopte den Gouverneur, door een groot aandeel in de buit wel te kunnen omkoopen en zoo straffeloosheid te verkrijgen. Het bleek hem echter al spoedig, dat hij buiten den waard gerekend had. De tijden waren voor zeerooverij nu eenmaal voorbij en ofschoon Kidd de voorzorg genomen had, eerst eens poolshoogte te nemen, voor hij in de haven van New-York binnenviel, wat hem trouwens als spoedig ongeraden bleek, werd hij, zoodra hij binnen het bereik der autoriteiten kwam, gearresteerd en naar Londen getransporteerd. Daar werd hij ter dood veroordeeld en opgehangen, waarna zijn lijk geruimen tijd in de nabijheid van London-Bridge als een afschrikkend voorbeeld voor anderen, aan kettingen hangende werd tentoongesteld.

De Britsche regeering maakte dus wel degelijk ernst met de bestrijding van de zeerooverij en het lot van Kidd maakte zoo grooten indruk, dat een moraliseerende poeet een gedicht maakte, dat nog langen tijd daarna in Engeland en Amerika zeer populair was. Een paar coupletten ervan volgen hier ten besluite nog: 
My name was Robert Kidd, when I sailed, when I sailed, My name was Robert Kidd, when I sailed, My name was Robert Kidd, God's laws I did forbid, when I sailed, And so wickedly I did, when I sailed.

I'd ninety bars of gold, as I sailed, as I sailed,

I'd ninety bars of gold, as I sailed,

I'd ninety bars of gold,

And dollars manyfold, as I sailed,

With riches uncontrolled, as I sailed.

Take warning now by me, for I must die, for I must die, Take warning now by me, for I must die,

Take warning now by me, And shun bad company, Lest you come to hell with me, for I die.

De gegevens voor dit opstel zijn voor een deel ontleend aan:

James Rodway, The West Indies and the Spanish Main. London 1896.

Cl. H. Haring, Ph. D. Trade and Navigation between Spain and the Indies. London 1912.

James Burney F. R. S. History of the Buccaneers of America. London 1912. 